\title{
Adult Wilms' tumour: an illustration of multimodality imaging characteristics
}

\author{
James William Ryan, Nicholas Hegarty, Tom Walsh, Ferdia Bolster
}

Department of Radiology, Mater Misericordiae University Hospital, Dublin, Ireland

Correspondence to Dr James William Ryan, jamesryannchd@gmail.com

Accepted 26 June 2017

\section{DESCRIPTION}

A 39-year-old woman was noted to have hypertension and a palpable abdominal mass at a routine general practitioner appointment. Her medical history was unremarkable.

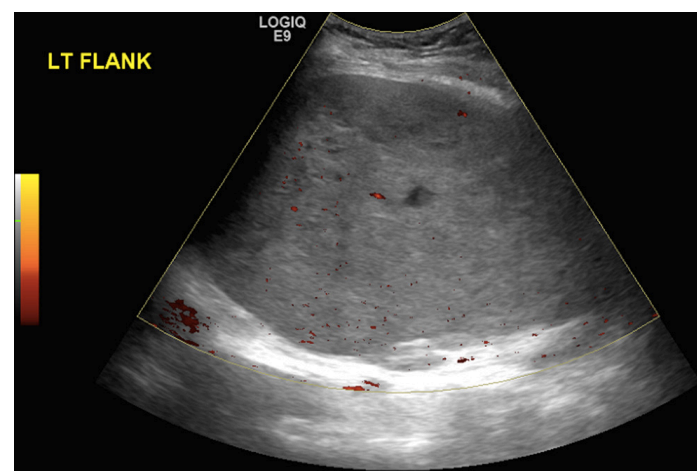

Figure 1 Ultrasound: there is a large mass arising from the left kidney measuring $22 \times 13 \mathrm{~cm}$. The renal mass demonstrated poor intrinsic vascularity on power Doppler assessment.

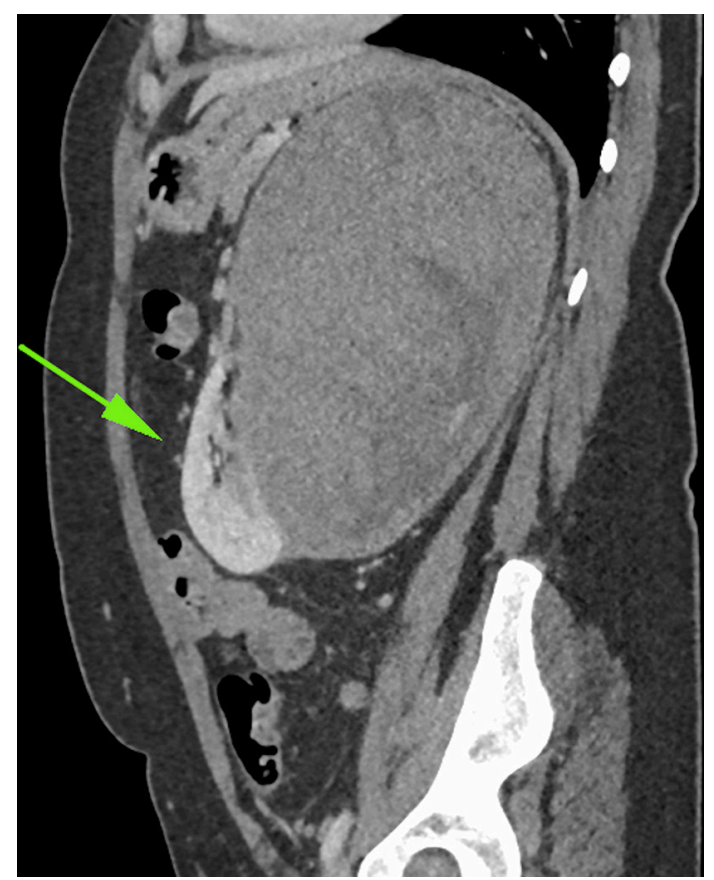

Figure 2 Sagittal contrast enhanced CT: There is a large heterogeneous mass arising from the left kidney. The arrow points to normal renal parenchyma at the lower pole. The mid and upper poles of the left kidney are largely replaced by hypoenhancing, heterogeneous tumour.

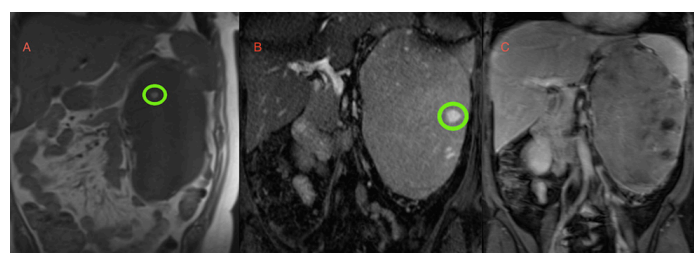

Figure 3 (A) Coronal T1-weighted MRI: the tumour is uniformly of low signal on T1-weighted imaging. There are regions of increased signal consistent with focal haemorrhage. (B) Coronal T2-weighted MRI: the large renal tumour is predominantly $\mathrm{T} 2$ isointense. The green circle highlights a region of increased signal consistent with focal cystic change. (C) Coronal MRI postgadolinium contrast: there is heterogeneous enhancement throughout the tumour.

An ultrasound of the abdomen demonstrated a large mass arising from the left kidney with a smooth echotexture and patchy areas of signal heterogeneity (figure 1).

A CT scan showed an expansile hypoenhancing solid tumour arising from the mid-upper pole of the left kidney (figure 2).

MRI demonstrated low tumour signal on T1-weighted images and isointense signal on T2-weighted sequences (figure 3A,B). There was heterogeneous postcontrast enhancement (figure 3C). There were focal signal abnormalities consistent with haemorrhagic and cystic change (figure 3A,B).

An open nephrectomy was performed (figure 4A). Histology showed a tumour composed of hyperchromatic spindle cells with an immunohistochemistry profile consistent with Wilms' tumour (figure 4B).

Wilms' tumour is an embryonal cancer affecting the kidneys. It is the most common solid renal mass and abdominal malignancy of childhood, with a prevalence of 1 case per 10000 population. ${ }^{1}$ Conversely,

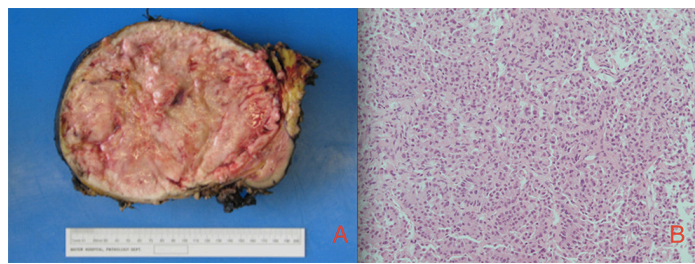

Figure 4 (A) Postnephrectomy surgical specimen. Please include description of macroscopic appearance from pathology report and the size. (B) Histology H\&E slide: there are hyperchromatic spindle cells consistent with Wilms' tumour. 


\section{Learning points}

- Wilms' tumour is the most common abdominal malignancy of childhood. ${ }^{1}$

- Adult Wilms' tumour is exceedingly rare but should be considered in the differential diagnosis for adult renal tumours. $^{2}$

- There are certain imaging characteristics that are associated with adult Wilms' tumour. These are described in detail with corresponding images. However, histology is required for definitive diagnosis. $^{3}$

it is very rare in adults, with an incidence rate of less than 0.2 per million per year. ${ }^{2}$ The imaging characteristics in our patient are congruent with those described in the literature for adult Wilms' tumour. ${ }^{3}$ Histology is required for definitive diagnosis.
Contributors JR: primary author. NH: performed surgery, provided clinical information. TW: assisted in surgery, provided clinical information. FB: senior author, reviewed and approved the manuscript.

Competing interests None declared.

Patient consent Obtained.

Provenance and peer review Not commissioned; externally peer reviewed.

(c) BMJ Publishing Group Ltd (unless otherwise stated in the text of the article) 2017. All rights reserved. No commercial use is permitted unless otherwise expressly granted.

\section{REFERENCES}

1 Dähnert W. Radiology review manual. Wolters Kluwer Health/Lippincott Williams Wilkins. 2011. 1227 p.

2 Mitry E, Ciccolallo L, Coleman MP, et al. Incidence of and survival from Wilms tumour in adults in Europe: data from the EUROCARE study. Eur I Cancer 2006:42:2363-8.

3 Wu J, Zhu Q, Zhu W, et al. CT and MRI imaging features and long-term follow-up of adult Wilms' tumor. Acta Radio/ 2016:57:894-900 http://acr.sagepub.com/lookup/doi/

Copyright 2017 BMJ Publishing Group. All rights reserved. For permission to reuse any of this content visit

http://group.bmj.com/group/rights-licensing/permissions.

BMJ Case Report Fellows may re-use this article for personal use and teaching without any further permission.

Become a Fellow of BMJ Case Reports today and you can:

- Submit as many cases as you like

- Enjoy fast sympathetic peer review and rapid publication of accepted articles

- Access all the published articles

Re-use any of the published material for personal use and teaching without further permission

For information on Institutional Fellowships contact consortiasales@bmjgroup.com

Visit casereports.bmj.com for more articles like this and to become a Fellow 